\title{
Genetic variability and high proportion of HIV-1 BF1 recombinant strains among vertically infected children in São Paulo, Brazil
}

\author{
Ana Carolina Soares de Oliveira*, Antonio Charlys da Costa, Vanessa Pouza Martinez, Maria Teresa Maidana, \\ Giret Regina Celia de Menezes Succi, Ester Cerdeira Sabino Esper, Georges Kallas, Sabri Saeed Sanabani
}

From 17th International Symposium on HIV and Emerging Infectious Diseases (ISHEID) Marseille, France. 23-25 May 2012

\section{Introduction}

The enormous genetic variability of human immunodeficiency virus type 1 (HIV-1) continues to present a major challenge for vaccine design and frustrate efforts to halt the epidemic. A proper understanding of this phenomenon is a prerequisite for proper epidemiology, genetic diagnosis, and successful drugs and vaccines. In this study, we undertook a detailed molecular epidemiological investigation on HIV-1 vertically-infected children born from 1993 to 2008 in the state of São Paulo, Brazil.

\section{Material and methods}

HIV-1 proviral DNA was extracted from the peripheral blood mononuclear cells of 48 participants. The near fulllength genomic (NFLG) and partial fragments were determined by overlapping nested PCR and direct sequencing. The data were phylogenetically analyzed.

\section{Results}

Of the 48 samples (median age 11.8 years, range 4-20.6 years) studied, 3 (6.2\%) NFLGs and 39 (81.2\%) partial fragments were successfully subtyped. Of the successfully subtyped sequences, 20 (47.6\%) were subtype B sequences, 17 (40.4\%) BF1 recombinants, and 5 (11.9\%) subclade F1. Two of the partial BF1 chimeric isolates shared an identical recombination structure. Predictions of viral tropism using the computer program geno2pheno [co receptor] for phenotype prediction were determined for 15 subjects. $\mathrm{X} 4$ or $\mathrm{X} 4$ dual or mixed-tropic viruses were seen in 3 (20\%) of participants and the V3 sequences of 12 patient virus strains $(80 \%)$ were predicted to be R5-tropic virus.

* Correspondence: carolina.soares@unifesp.br

São Paulo Institute of Tropical Medicine, São Paulo, Brazil

\section{Conclusions}

Our data provided evidence of unexpectedly high proportion of BF1 recombinants viruses transmitted from the first mother-to-child since the earliest days of the epidemic to the present time in Brazil. These findings offers additional insights to understanding the diversity of HIV-1 strains currently circulating in Brazil, with future implications for diagnosis, therapy, and efficient vaccine development.

Published: 25 May 2012

\section{doi:10.1186/1742-4690-9-S1-P4}

Cite this article as: Soares de Oliveira et al:: Genetic variability and high proportion of HIV-1 BF1 recombinant strains among vertically infected children in São Paulo, Brazil. Retrovirology 2012 9(Suppl 1):P4.

Submit your next manuscript to BioMed Central and take full advantage of:

- Convenient online submission

- Thorough peer review

- No space constraints or color figure charges

- Immediate publication on acceptance

- Inclusion in PubMed, CAS, Scopus and Google Scholar

- Research which is freely available for redistribution

Submit your manuscript at www.biomedcentral.com/submit

\section{Biomed Central}

